\title{
MAGNETIC BEHAVIOR AND ANTIBACTERIAL ACTIVITY OF IRON (III) COMPLEXES
}

\author{
PIEDAD CORTÉS-CORTÉS $S^{l}$, ANA MARÍA ATRIA ${ }^{1 *}$, MARTÍN CONTRERAS ${ }^{\prime}$, \\ OCTAVIO PEÑA' ${ }^{2}$ KATIA FERNÁNDEZ $Z^{3}$, GINO CORSINI ${ }^{3}$ \\ ${ }^{I}$ Facultad de Ciencias Quimicas y Farmacéuticas, Universidad de Chile. Santiago, Chile. \\ ${ }^{2}$ L.C.S.I.M./UMR 6511CNRS/Institut de Chimie de Rennes, Université de Rennes I. Rennes, Francia. \\ ${ }^{3}$ Laboratorio de Bacteriología Molecular, Facultad de Ciencias de la Salud, Universidad Diego Portales. Santiago, Chile. \\ (Received: 5 June 2007 - Accepted: 12 March 2008)
}

\begin{abstract}

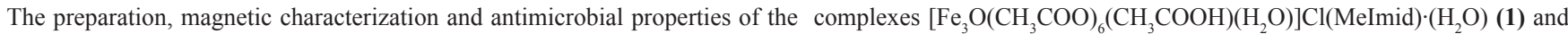
$\left[\mathrm{Fe}_{4} \mathrm{O}_{2}\left(\mathrm{CH}_{3} \mathrm{COO}\right)_{7} \mathrm{O}_{2}(\mathrm{BPA})_{2}\left(\mathrm{H}_{2} \mathrm{O}\right)\right] \cdot \mathrm{Cl} \cdot 1.25\left(\mathrm{CH}_{3} \mathrm{CH}_{2} \mathrm{OH}\right)\left(\mathrm{H}_{2} \mathrm{O}\right)(2)$, where MeImid is 2-methyl-imidazolium and BPA is 2,2'-bipyridine, are described.

The variable temperature susceptibilities of these complexes were investigated in the temperature range 2-300K. The data have been modeled on the assumption of "butterfly" arranged for (2) and equilateral triangle of ferric ions for (1).

The antimicrobial activities of these complexes have been screened in vitro against different bacterial strains. The complexes (1) and (2) display activity over Gram negative bacteria and these compounds not present activity over Gram positive strains. These complexes have bacteriostatic effect over bacterial target. The toxicity analyses of iron complexes showed these have cytotoxicity effect to values around the MIC on human cell.
\end{abstract}

Keyword: iron complexes, magnetism, antibacterial activities.

\section{INTRODUCTION}

The transition metals play a wide variety of roles in biology. Some metals are essential for biological function and are found in enzymes and cofactors required for various processes. Transition metals also plays a role as drugs to treat of variety of diseases and conditions ${ }^{1-3}$.

Particularly important in the biological system is the iron ion. For example E. coli devotes almost 50 genes to proteins involved in iron uptake, while the potential for mammalian tumors to develop can be estimated by the density of their transferrin receptors, which are required for iron uptake and therefore essential for cell growth ${ }^{4}$.

From a biological point of view, oxo- and hydroxo-bridged diiron units are wide occurrence in biology and perform a range of activities such as oxygen transport ${ }^{5}$ and hydroxylation of alkanes ${ }^{6}$.

The $\left\{\mathrm{Fe}_{3} \mathrm{O}\right\}^{7+}$ units has been proposed as the smallest building block of the ferritin core ${ }^{7,8}$, since it is know that hemerythrin, methane monooxygenase and ribonucleotide reductase have diiron active sites with $\mu$-oxo and $\mu$-carboxylate bridges ${ }^{9,10}$. The ferric core of ferritine, exhibits the phenomenon of super paramagnetism ${ }^{11}$. Related system are the iron oxo complexes, which contain $\mathrm{Fe}(\mathrm{III})$ ions disposed in a "Butterfly" $\left[\mathrm{Fe}_{4} \mathrm{O}_{2}\right]^{8+}{ }^{12,13}$.

As a contribution to the general understanding of oxo-bridged polynuclear iron complexes we present herein the preparation, magneto-structural characterization of two oxo-bridged iron(III) ionic complexes, viz. $\left[\mathrm{Fe}_{3} \mathrm{O}\right.$ $\left.\left(\mathrm{CH}_{3} \mathrm{COO}\right)_{6}\left(\mathrm{CH}_{3} \mathrm{COOH}\right)\left(\mathrm{H}_{2} \mathrm{O}\right)\right] \mathrm{Cl}(\mathrm{MeImid}) \cdot\left(\mathrm{H}_{2} \mathrm{O}\right)(\mathbf{1})$ and $\left[\mathrm{Fe}_{4} \mathrm{O}_{2}\left(\mathrm{CH}_{3} \mathrm{COO}\right)_{7}\right.$ $\left.\mathrm{O}_{2}(\mathrm{BPA})_{2}\left(\mathrm{H}_{2} \mathrm{O}\right)\right] \cdot \mathrm{Cl} \cdot 1.25\left(\mathrm{CH}_{3} \mathrm{CH}_{2} \mathrm{OH}\right)\left(\mathrm{H}_{2} \mathrm{O}\right)(2)$, where MeImid $=2$-methylimidazolium and BPA is $2,2^{\prime}$-bipyridine. We also studied the antibacterial activity, the action mechanism and cytotoxic effect on human cell of these two new iron oxo complexes.

\section{EXPERIMENTAL SECTION}

\section{Reagents}

Sodium acetate (Aldrich), 2,2'-bipyridine (Aldrich), iron (III) chloride (Aldrich) were used without further purification. The solvent (Fluka p.a. absolute ethanol) was used as received.

\section{Synthesis}

The complexes were synthesized according to the reported procedure by McCusker, et $\mathrm{al}^{14}$. To an orange solution of $\mathrm{FeCl}_{3} \cdot 6 \mathrm{H}_{2} \mathrm{O}(2.67 \mathrm{mmol})$ in ethanol $(50 \mathrm{~mL})$ was treated with sodium acetate $(6.63 \mathrm{mmol})$ and the respective ligand $(1.43 \mathrm{mmol})$. The resultant solution was stirred at room temperature for 10 min. An excess of $\mathrm{KClO}_{4}$ was added to the reaction mixture, and the resulting solution was stirred over night at room temperature. In both case a fine redbrown solid was collect by filtration. The solid was recrystallized in EtOH/ $\mathrm{Et}_{2} \mathrm{O}$.

Elemental analysis $(\mathrm{C}, \mathrm{H}, \mathrm{N})$ were performed on a Carlo-Erba EA 1108 Instrument.

For complex (1) Anal. Found: C:26.92, H:4.09, N:3.65; Calc: C:27.05, H:4.14 N:3.71 and for complex (2) Anal. Found: C:39.21, H:4.71, N:4.98;
Calc: C: $39.33, \mathrm{H}: 4.75, \mathrm{~N}: 5.03$

The chemical analyses of (1) and (2) were in agreement with the structures described in reference ${ }^{15}$.

\section{Magnetic susceptibility measurements.}

The magnetic susceptibility data were determined for the power samples over the temperature range $2-300 \mathrm{~K}$ by using a SQUID magnetometer (QUANTUM DESING MODEL MPMS-XL5 instrument) with a field of $0.1 \mathrm{~T}$.

All susceptibility data were corrected for the diamagnetism of constituent atoms using Pascal's constant ${ }^{16}$.

\section{EPR spectra}

EPR spectra were recorder in X band $(9.85 \mathrm{GHz})$ on a Bruker ECS 106 spectrometer using a rectangular cavity with a $50 \mathrm{KHz}$ field modulation.

\section{Antibacterial activity}

Bacterial strains used in this study are property of the Molecular Bacteriology Laboratory collection (Universidad Diego Portales). Staphylococcus aureus AB68, Bacillus cereus UDP346, Pseudomonas aeruginosa SJD1 and Salmonella enteritidis UDP455 strains were isolated from clinical samples while the Escherichia coli ATCC25922 and Klebsiella pneumoniae ATCC13833 strains was obtained from American Type Culture Collection.

Bacteria were grown in Mueller Hinton agar (Difco) or Mueller Hinton broth (Difco) for 16 to $24 \mathrm{~h}$ at $37{ }^{\circ} \mathrm{C}$ in an incubator. The antibacterial activity of the complexes was tested in vitro using the paper disk diffusion method ${ }^{17}$. The complexes under study were dissolved in absolute ethanol and added to sterile $6 \mathrm{~mm}$ diameter paper disk. The quantitative antibacterial activity was determined using the minimum inhibitory concentration method (MIC) ${ }^{18}$.

\section{Antibacterial mechanism}

The antibacterial effect of the complexes was tested in vitro using the chromogenic plate test assay ${ }^{19}$. E. coli BL21(DE3) which contains a chromosomal IPTG-inducible $\beta$-galactosidase gene, was used for the assays. First, an inoculum of this strain was grown overnight in $2 \mathrm{~mL}$ of Mueller Hinton medium, at $37{ }^{\circ} \mathrm{C}$ with shaking. Then, a soft agar incubation mix containing $5 \mathrm{~mL}$ of $0.8 \%$ agar previously melted at $45^{\circ} \mathrm{C}, 0.1 \mathrm{~mL}$ of the bacterial cell inoculum, $0.01 \mathrm{~mL}$ of $1 \mathrm{mM}$ IPTG, and $0.1 \mathrm{~mL}$ of $50 \mathrm{mg} / \mathrm{mL} X-G a l$ was vortex mixed and carefully overlaid on Mueller Hinton agar plates prepared the day before. Once soft agar was solidified and dried (1-2 h), a disk containing 400 $\mu \mathrm{g}$ of iron complexes or ampicillin was deposited on the soft agar layer. The plates were incubated at $37^{\circ} \mathrm{C}$ for $12-24 \mathrm{~h}$. After incubation, inhibition zones were visually inspected by color formation along the edge of the disks and the plates were photographed. Only compounds causing cellular lysis produce a blue-colored edge at the inhibition zone.

Cytotoxic effect

The cytotoxicity of the iron complexes was tested in vitro on human kidney 
embryonic cells (HEK293 cells) grown in microplates with DMEM medium plus $10 \%$ bovine fetal serum. After $24 \mathrm{~h}$ incubation with the iron complexes, the number of dead cells was determined with a vital dye trypan blue assay ${ }^{20}$.

\section{RESULTS AND DISCUSSION}

\section{Structure Descriptions}

Both structures $\left[\mathrm{Fe}, \mathrm{O}\left(\mathrm{CH}_{3} \mathrm{COO}\right)\left(\mathrm{CH}_{2} \mathrm{COOH}\right)\left(\mathrm{H}_{2} \mathrm{O}\right)\right] \mathrm{Cl}(\mathrm{MeImid}) \cdot\left(\mathrm{H}_{2} \mathrm{O}\right)$ (1) and $\left[\mathrm{Fe}_{4} \mathrm{O}_{2}\left(\mathrm{CH}_{3} \mathrm{COO}\right)_{7} \mathrm{O}_{2}(\mathrm{BPA})_{2}\left(\mathrm{H}_{2} \mathrm{O}\right)\right] \cdot \mathrm{Cl} \cdot 1.25\left(\mathrm{CH}_{3} \mathrm{CH}_{2} \mathrm{OH}\right)\left(\mathrm{H}_{2} \mathrm{O}\right)$ (2) can be described in general terms as formed by isolated cationic clusters composed of $\mathrm{Fe}^{3+}$ ions coordinated to oxo and acetate anions.

The complex (1) consists in the triangular ensemble of three Fe(III) ions with the center oxo bridge which is stabilized by seven acetate ligands and two water molecules (Figure 1). Each iron atoms exhibit a distorted octahedral $\mathrm{FeO}$ coordination environment. The complex (2) comprised an innermost core of two iron atoms doubly bridged by oxygen atoms, the oxo units, which in turn connect outward to the remaining iron atoms (one each), the second and third iron atom, to fulfill their $\mu_{3}$ - coordination (Figure 2).

These clusters, in turn, are stabilized by external anionic groups formed by a central chloride ion surrounded by different solvates to which the anion is tightly bound through H-bonding. Figures 1 and 2 present views of both structures. The detailed discussion of the X-ray structure, data collection, structure solution, and refinement of these complexes can be found in reference

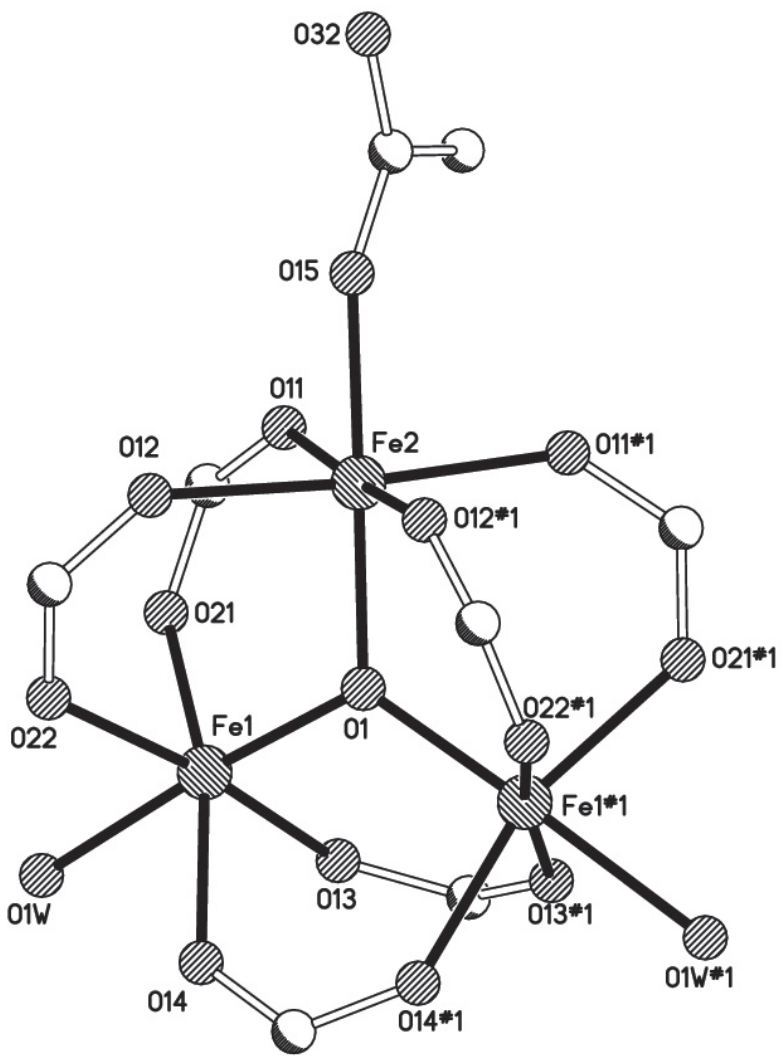

Figure 1. Close view of the trimeric core in (1), with hydrogen and (some) carbon atoms removed, for clarity.

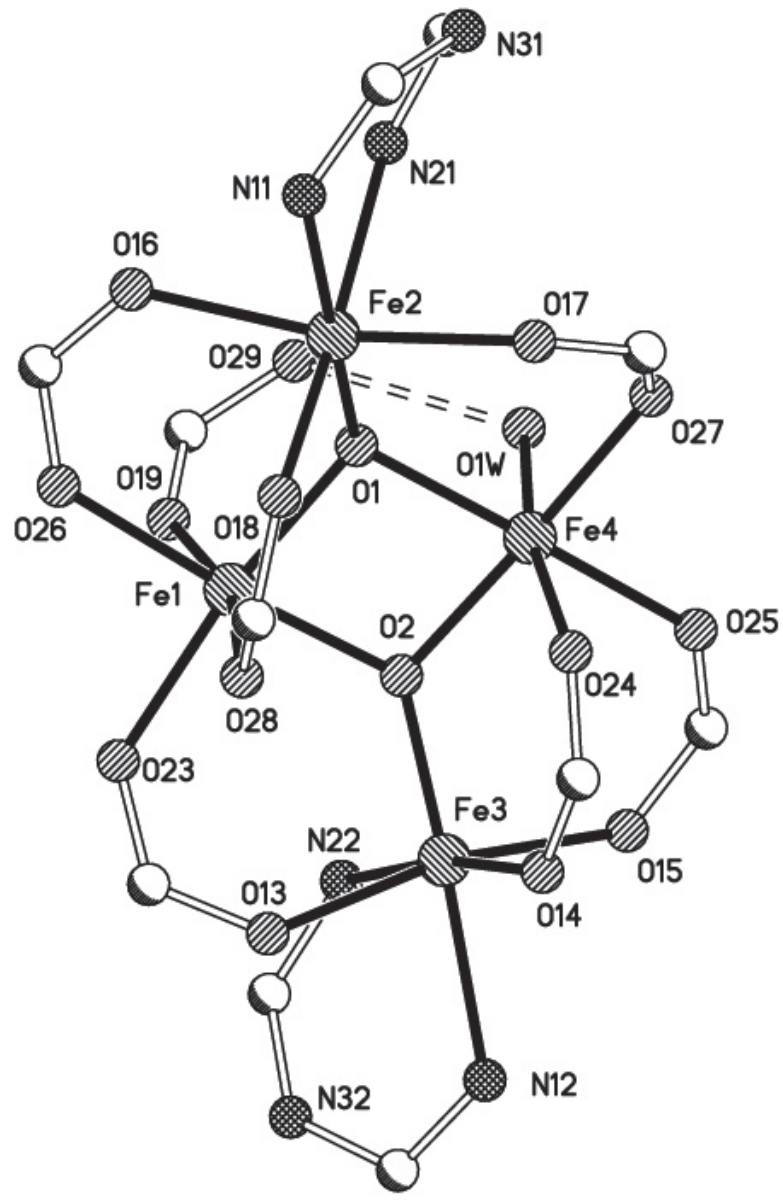

Figure 2. Close view of the tetrameric core in (2), with hydrogen and (some) carbon atoms removed, for clarity. In double dashed lines, the intramolecular H-bond connecting O1W and acetato 9 .

\section{Magnetic susceptibility studies}

The study of magnetic properties of the compounds (1) and (2) were performed through magnetic susceptibility measurements, on polycrystalline samples in the temperature range $5-300 \mathrm{~K}$ in $0.1 \mathrm{~T}$ field.

For the complex $\left[\mathrm{Fe}_{3} \mathrm{O}\left(\mathrm{CH}_{3} \mathrm{COO}\right)_{6}\left(\mathrm{CH}_{3} \mathrm{COOH}\right)\left(\mathrm{H}_{2} \mathrm{O}\right)\right] \mathrm{Cl}(\mathrm{MeImid}) \cdot\left(\mathrm{H}_{2} \mathrm{O}\right)$ (1) the temperature dependences of their magnetic susceptibilities were plotted in Figure 3, in the form of $\chi_{M}{ }^{-1} v s \mathrm{~T}$ and $\chi_{\mathrm{M}} \mathrm{T} v s \mathrm{~T}$.

The inverse of the molar magnetic susceptibility decreases with decreasing temperature over the whole range.

The $\chi_{\mathrm{M}} \mathrm{T}$ versus $\mathrm{T}$ plot shows that the $\chi_{\mathrm{M}} \mathrm{T}$ product gradually decreases from $3.43 \mathrm{~cm}^{3} \mathrm{~mol}^{-1} \mathrm{~K}$ at $300 \mathrm{~K}$ to $0.825 \mathrm{~cm}^{3} \mathrm{~mol}^{-1} \mathrm{~K}$ at $6 \mathrm{~K}$. The observed effective magnetic moment per molecule at $6 \mathrm{~K}$ is $2.56 \mathrm{MB}$, while at room temperature it is $5.23 \mathrm{MB}$. This last value is smaller than expected for three non interacting iron(III) ions. The data are suggestive of a coupling occurs between the ferric ions.

In light of the structure of (1), the system was assumed to consist of three identical metal ions which arranged at the corner of an equilateral triangle, producing three equal interactions. The magnetic interactions can be illustrated by means of scheme 1 

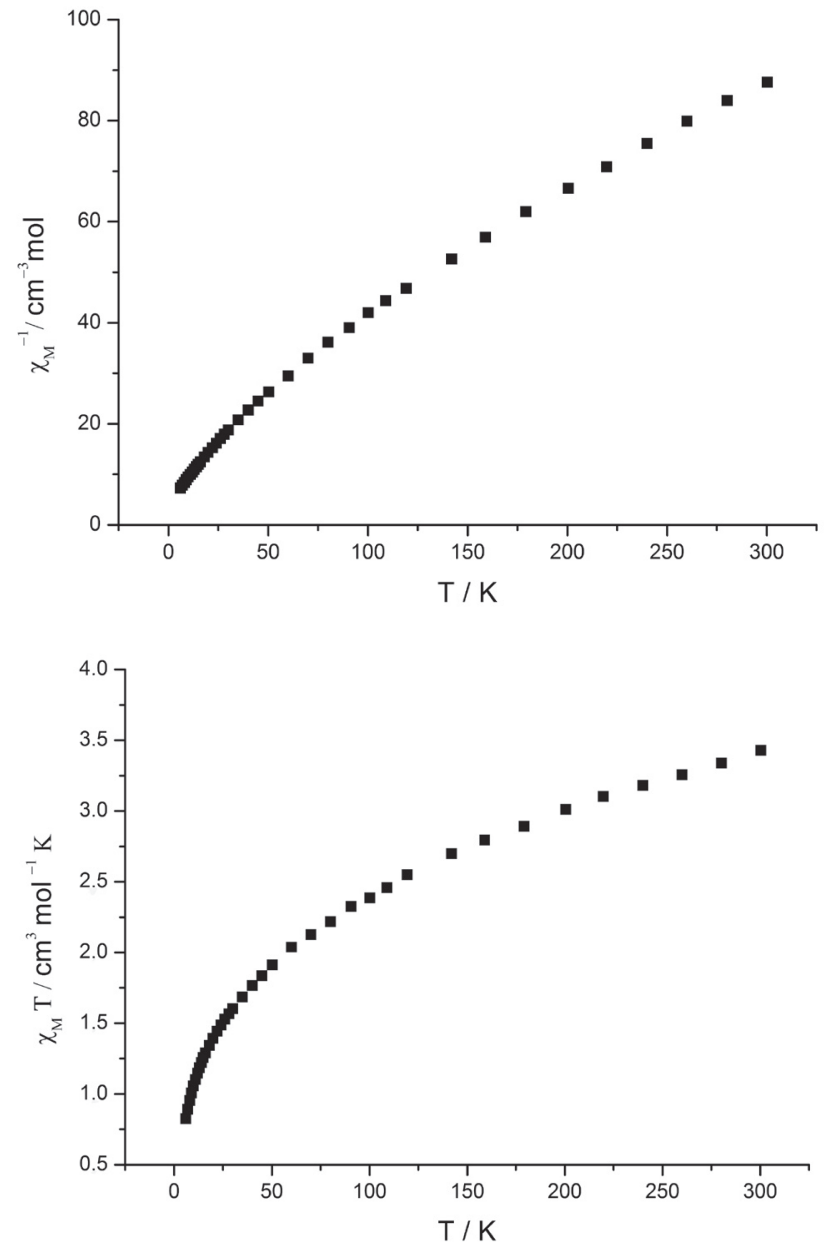

Figure 3. Plot of the temperature dependence of $\chi_{\mathrm{M}}{ }^{-1}$ and $\chi_{\mathrm{M}} \mathrm{T}$ for $\left[\mathrm{Fe}_{3} \mathrm{O}(\mathrm{C}\right.$ $\left.\left.\mathrm{H}_{3} \mathrm{COO}\right)_{6}\left(\mathrm{CH}_{3} \mathrm{COOH}\right)\left(\mathrm{H}_{2} \mathrm{O}\right)\right] \cdot \mathrm{Cl}(\mathrm{MeImid}) \cdot\left(\mathrm{H}_{2} \mathrm{O}\right)$ (1)

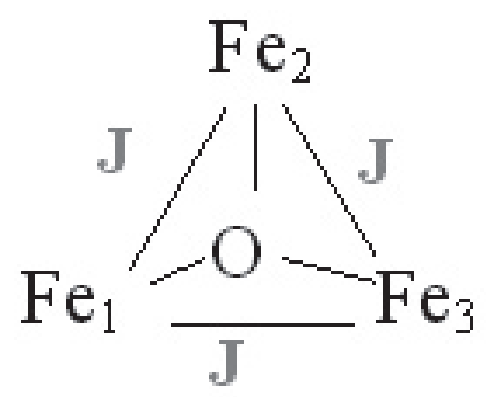

Scheme 1

The appropriate spin Hamiltonian to treat this problem is $H=-2 J$ $\left[\left(S_{1} \cdot S_{2}\right)+\left(S_{2} \cdot S_{3}+\left(S_{1} \cdot S_{3}\right)\right]\right.$ where, J is the exchange coupling constant between the pair of iron (III) ion. $S_{1}, S_{2}$ and $S_{3}$ are the spin operator associated with the local spin $S_{1}=S_{2}=S_{3}=5 / 2$.

The magnetic susceptibility expression is giving as
$\chi=\frac{N g^{2} \beta^{2}}{12 k T}\left(\frac{340+455 e^{15 x}+429 e^{28 x}+330 e^{39 x}+210 e^{48 x}+105 e^{55 x}+20 e^{60 x}+e^{63 x}}{4+7 e^{15 x}+9 e^{28 x}+10 e^{48 x}+9 e^{55 x}+4 e^{60 x}+e^{63 x}}\right)$

Equation 1

where $\mathrm{x}=\exp (\mathrm{J} / \mathrm{kT})$ and $\chi_{\mathrm{M}}, \mathrm{k}$ parameters in equation 1 have their usual meanings.

The magnetic susceptibility expression was fitted to the experimental magnetic data by using a non linear least-squares fitting by minimizing the function $\mathrm{R}=\Sigma\left[\left(\chi_{\mathrm{M}}\right)_{\mathrm{obs}}-\left(\chi_{\mathrm{M}}\right)_{\text {call }}^{2} / \Sigma\left[\left(\chi_{\mathrm{M}}\right)_{\mathrm{obs}}\right]^{2}\right.$.

A g-value of 1.9 was obtained from EPR spectra and used as a constant in the least-squares fitting process. The best fitting parameter obtained for (1) is $\mathrm{J}=-2.71 \mathrm{~cm}^{-1}$ with $\mathrm{R}=8.79 \times 10^{-4}$. The solid line in the Figure 4 was calculated with this parameter. The results of the fit are indicative of weak antiferromagnetic exchange within the cluster.

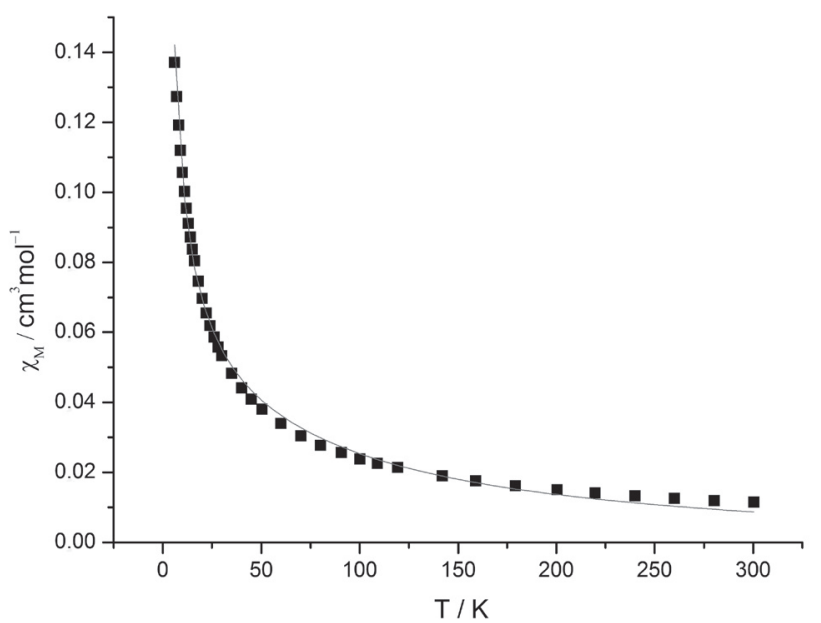

Figure 4. Thermal dependence of $\chi_{\mathrm{M}}$ for $\left[\mathrm{Fe}_{3} \mathrm{O}\left(\mathrm{CH}_{3} \mathrm{COO}\right)_{6}\left(\mathrm{CH}_{3} \mathrm{COO}\right.\right.$ $\left.\mathrm{H})\left(\mathrm{H}_{2} \mathrm{O}\right)\right] \cdot \mathrm{Cl}(\mathrm{MeImid}) \cdot\left(\mathrm{H}_{2} \mathrm{O}\right)(\mathbf{1})$. The solid line represents the best fit of the experimental data.

The crystal structure of an iron (III) complex of this type, is the compound $\left[\mathrm{Fe}, \mathrm{O}(\mathrm{TIEO})_{2}\left(\mathrm{O}_{2} \mathrm{CPh}\right)_{2} \mathrm{Cl}_{3}\right]$ (3) reported by Lippard et al., where the ligand TIEOH is the 1,1,2-tris(N-methylimidazol-2-yl)-3-hidroxyethane, and $\mathrm{O}_{2} \mathrm{CPh}$ is benzoate ${ }^{21}$.

Comparison of the structure reported here complex (2) with that of, complex (3) indicates that both structures are similar. We note that in both cases the Fe atoms placed in the triangular array. In the complex (3) the Fe-Fe distances are $\mathrm{Fe}(1)-\mathrm{Fe}(3)=3.018(1) \AA, \mathrm{Fe}(2)-\mathrm{Fe}(3)=3.027(3) \AA, \mathrm{Fe}(1)-\mathrm{Fe}(2)$ $=3.667(1) \AA$. This three iron atoms defined an isosceles triangle. The Fe-O$\mathrm{Fe}$ angles are $\mathrm{Fe}(1)-\mathrm{O}(3)-\mathrm{Fe}(2)=159.1(3)^{\circ}, \mathrm{Fe}(1)-\mathrm{O}(3)-\mathrm{Fe}(3)=100.3(3)^{\circ}$ and $\mathrm{Fe}(2)-\mathrm{O}(3)-\mathrm{Fe}(3)=100.5(3)^{\circ}$. Each iron atom has pseudooctahedral symmetry, with two nitrogen, three oxygen and one chlorine atom in the coordination spheres of the equivalent $\mathrm{Fe} 1$ and $\mathrm{Fe} 2$ atoms. Five oxygen and one chlorine atom constitute the coordination sphere of the unique $\mathrm{Fe} 3$ atom.

The exchange interaction in this $\mathrm{Fe}_{3}$-trimer, complex (3), is discusses in terms of the isosceles triangular array of metal atoms. The analysis yielded $\mathrm{J}_{12}=-55 \mathrm{~cm}^{-1}$ and $\mathrm{J}_{13}=\mathrm{J}_{23}=-8.0 \mathrm{~cm}^{-1}$, with the large antiferromagnetic coupling interaction occurring between iron centers linked by the short $\mu$-oxo bridge bonds.

In the complex $\left.(\mathbf{1}) \mathrm{Fe}_{3} \mathrm{O}\left(\mathrm{CH}_{3} \mathrm{COO}\right)_{6}\left(\mathrm{CH}_{3} \mathrm{COOH}\right)\left(\mathrm{H}_{2} \mathrm{O}\right)\right] \cdot \mathrm{Cl}(\mathrm{MeImid}) \cdot\left(\mathrm{H}_{2} \mathrm{O}\right)$ the $\mathrm{Fe}_{3} \mathrm{O}$ core is much more symmetric than the complex (3). The average value distances $\mathrm{Fe}-\mathrm{Fe}$ is $3.313 \AA$, defining an equilateral triangle. The coordination spheres of the atoms of iron are constituted, in this case, by only oxygen atoms. The Fe-O1-Fe angle of the bridge are extremely close to $120^{\circ}\left(\mathrm{Fe}_{1}-\mathrm{O}_{1}-\mathrm{Fe}_{2}=\right.$ $\mathrm{Fe}_{1 \mathrm{~A}}-\mathrm{O}_{1}-\mathrm{Fe}_{2}=119.5(3) ; \mathrm{Fe}_{1}-\mathrm{O}_{1}-\mathrm{Fe}_{2}=121.0(5)$, and the $\mathrm{Fe}-\mathrm{O}_{\mathrm{oxo}}$ distances are $\mathrm{Fe}(1)-\mathrm{O}(1)=1.894 \AA ; \mathrm{Fe}(2)-\mathrm{O}(1)=1.950 \AA$ and $\mathrm{Fe}(1 \mathrm{~A})-\mathrm{O}(1)=1.894 \AA$.

The magnetic properties on the title complex differ greatly in relation to complex (3), in this case the exchange constant is $\mathrm{J}=-2,71 \mathrm{~cm}^{-1}$.

The difference in the magnitude of exchange coupling must be associate to smaller number of the bridged acetate ligands between the metal ions.

For the complex $\left[\mathrm{Fe}_{4} \mathrm{O}_{2}\left(\mathrm{CH}_{3} \mathrm{COO}\right)_{7}\left(\mathrm{H}_{2} \mathrm{O}\right)(\mathrm{BPA})_{2}\right] \mathrm{Cl} \cdot\left(\mathrm{CH}_{3} \mathrm{CH}_{2} \mathrm{OH}\right)_{2}$ 
$\left(\mathrm{H}_{2} \mathrm{O}\right)(2)$ the inverse susceptibility and $\chi_{\mathrm{M}}^{\mathrm{T}}$ product are plotted as a function of temperature in the Figure 5 The graph of reciprocal molar susceptibilities versus temperature not follow the Curie law.
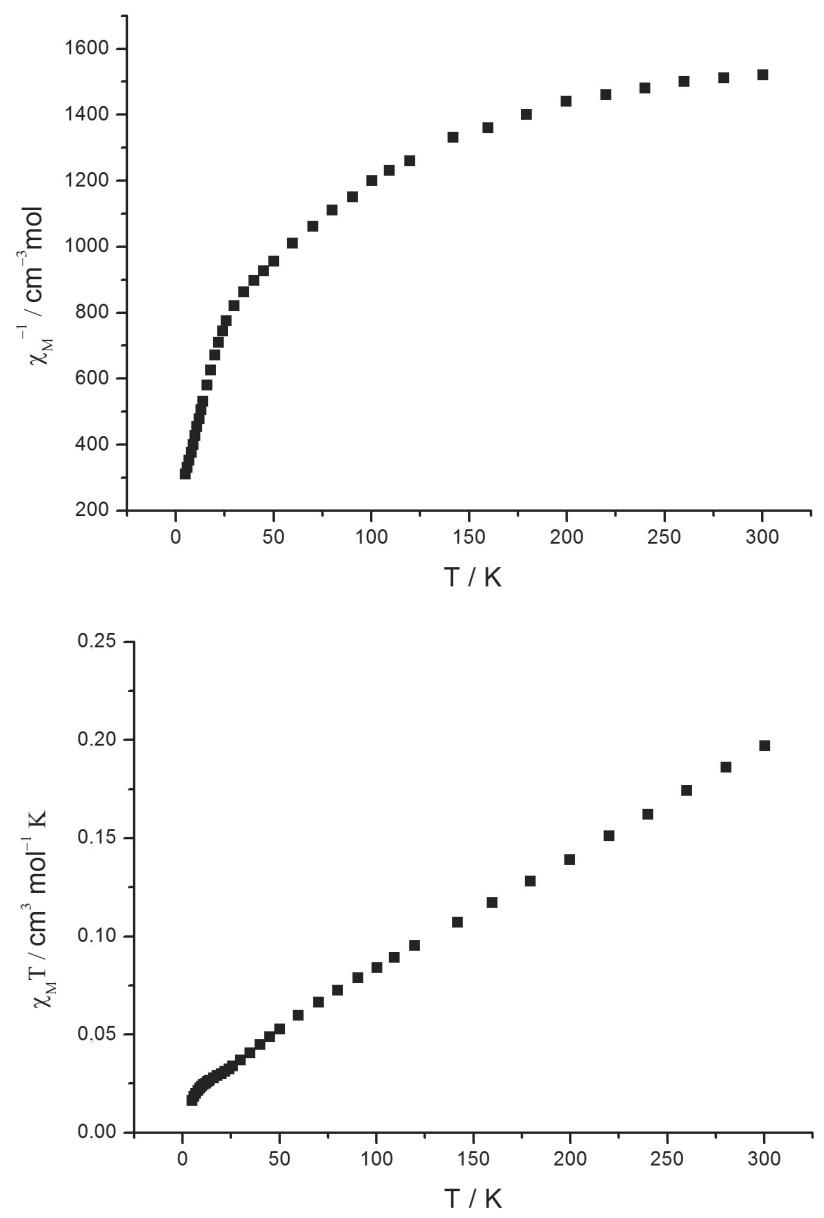

Figure 5. Plot of the temperature dependence of $\chi_{\mathrm{M}}{ }^{-1}$ and $\chi_{\mathrm{M}} \mathrm{T}$ for $\left[\mathrm{Fe}_{4} \mathrm{O}_{2}\left(\mathrm{CH}_{3} \mathrm{COO}\right)_{7}\left(\mathrm{H}_{2} \mathrm{O}\right)(\mathrm{BPA})_{2}\right] \mathrm{Cl} \cdot\left(\mathrm{CH}_{3} \mathrm{CH}_{2} \mathrm{OH}\right)_{2} \cdot\left(\mathrm{H}_{2} \mathrm{O}\right)(2)$.

The $\chi_{\mathrm{M}} \mathrm{T}$ product monotonically decreases from $0.197 \mathrm{~cm}^{3} \mathrm{~mol}^{-1} \mathrm{~K}$ at 300 to $0.0162 \mathrm{~cm}^{3} \mathrm{~mol}^{-1} \mathrm{~K}$ at $5 \mathrm{~K}$, the calculated magnetic moments per molecule are $1.26 \mathrm{BM}$ and $0.36 \mathrm{BM}$ respectively. The value of magnetic moment (1.26BM) is smaller than expected for four non interacting metallic centers with $\mathrm{S}=5 / 2$. This is indicative of the antiferromagnetic interactions within the cluster.

In the core $\mathrm{Fe}_{4} \mathrm{O}_{2}$, the distances $\mathrm{Fe}_{1}-\mathrm{Fe}_{2}, \mathrm{Fe}_{1}-\mathrm{Fe}_{3}, \mathrm{Fe}_{2}-\mathrm{Fe}_{4}$ and $\mathrm{Fe}_{3}-\mathrm{Fe}_{4}$ are equals and $\mathrm{Fe}_{1}-\mathrm{Fe}_{4}$ is large, this suggest the pairwise magnetic exchange interactions between pairs $\mathrm{Fe}$ (III)-Fe(III) ions are equivalent such as $\mathrm{J}_{12}=\mathrm{J}_{13}=$ $\mathrm{J}_{24}=\mathrm{J}_{34}=\mathrm{J}_{2}$, and the coupling between the $\mathrm{Fe}_{1}-\mathrm{Fe}_{4}$ is different and equal to $\mathrm{J}_{6}$.

The spin Hamiltonian describing the isotropic exchange interaction for a tetranuclear "butterfly" arrangement of metal ions is giving by equation 2 and the scheme 2 shows the magnetic model used in the analysis of the susceptibilities for this complex, which include two different J values.

$$
H=-2 \mathrm{~J}_{\mathrm{a}}\left(\mathrm{S}_{1} \cdot \mathrm{S}_{2}+\mathrm{S}_{1} \cdot \mathrm{S}_{3}+\mathrm{S}_{3} \cdot \mathrm{S}_{4}+\mathrm{S}_{4} \cdot \mathrm{S}_{2}\right)-2 \mathrm{~J}_{\mathrm{b}}\left(\mathrm{S}_{1} \cdot \mathrm{S}_{4}\right), \quad \text { Equation } 2
$$

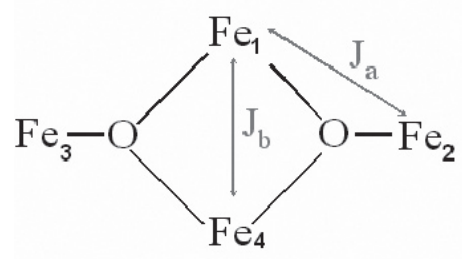

Scheme 2
The expression for the molar paramagnetic susceptibility, $\chi_{\mathrm{M}}$ derived by using the Van Vleck equation ${ }^{14}$. The solid line in the Figure 6 represent the result obtained from fitting to the experimental data using a least-square fitting routine with the EPR determined $\mathrm{g}$ value of 1.9 as a constant parameter. The best fit was found with $\mathrm{J}=-16.20 \mathrm{~cm}^{-1}$ and $\mathrm{J}_{\mathrm{b}}=-9.78 \mathrm{~cm}^{-1}$, with $\mathrm{R}=6.22 \times 10^{-3}$ $\left(\mathrm{R}=\Sigma\left[\left(\chi_{\mathrm{M}}\right)_{\mathrm{obs}}-\left(\chi_{\mathrm{M}}\right)_{\mathrm{cal}}^{2} / \Sigma\left[\left(\chi_{\mathrm{M}}\right)_{\mathrm{obs}}\right]^{2}\right)\right.$.

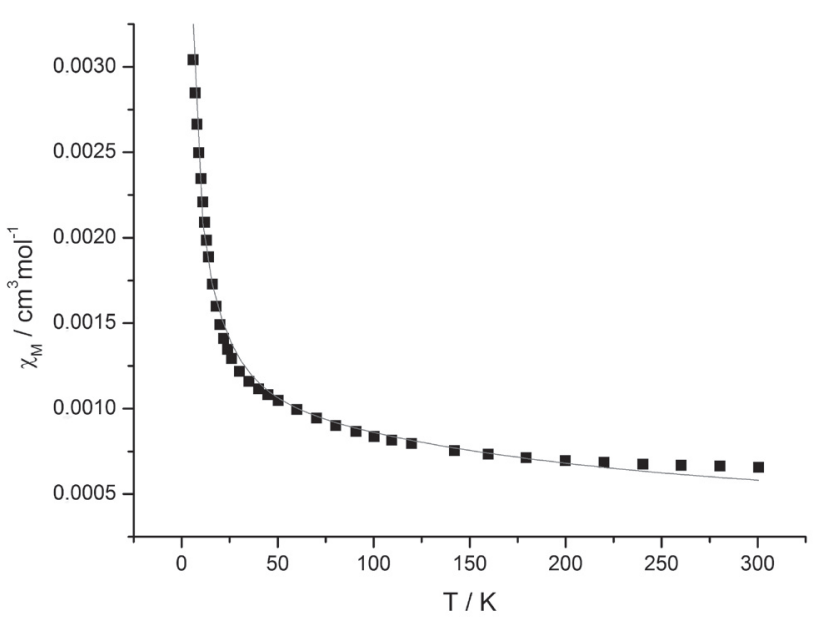

Figure 6. Thermal dependence of $\chi_{\mathrm{M}}$ for $\left[\mathrm{Fe}_{4} \mathrm{O}_{2}\left(\mathrm{CH}_{3} \mathrm{COO}\right)_{7}\left(\mathrm{H}_{2} \mathrm{O}\right)(\mathrm{BPA})_{2}\right]$ $\mathrm{Cl} \cdot\left(\mathrm{CH}_{3} \mathrm{CH}_{2} \mathrm{OH}\right)_{2} \cdot\left(\mathrm{H}_{2} \mathrm{O}\right)$ (2). The solid line represents the best fit of the experimental data.

These values are indicative of antiferromagnetic interaction between iron centers.

An examination of the Table 1, in which the magnetic properties of other complexes of this kind are tabulated reveals that, $\mathrm{J}_{\mathrm{b}}$ constant is much less than $\mathrm{J}_{\mathrm{a}}$ constant. The difference in the magnitude of the interactions, e.g J interaction greater than $\mathrm{J}_{\mathrm{b}}$, can be associated to spin frustration in these systems. The strength of the $\mathrm{J}_{\mathrm{a}}$ interaction relative to $\mathrm{J}_{\mathrm{b}}$ interaction is such that the natural tendency for the spin vectors on $\mathrm{Fe}(1)$ and $\mathrm{Fe}(4)$ to align antiparallel is overcome and the result is an ferromagnetic alignment of $\mathrm{Fe}(1) \mathrm{Fe}(4)$ spin vectors and frustration of that spin spin interaction .

Table 1. Comparative magnetic data for $\mathrm{Fe}_{4} \mathrm{O}_{2}$ complexes.

\begin{tabular}{|l|c|c|c|}
\hline \multicolumn{1}{|c|}{ Compounds } & $\mathrm{J}_{\mathrm{a}} / \mathrm{cm}^{-1}$ & $\mathrm{~J}_{\mathrm{b}} / \mathrm{cm}^{-1}$ & \\
\hline$\left[\mathrm{Fe}_{4} \mathrm{O}_{2}\left(\mathrm{O}_{2} \mathrm{CCH}\right)_{7}(\text { bpy })_{2}\right]^{+}$ & -91.0 & -17.8 & Ref. 14 \\
\hline$\left[\mathrm{Fe}_{4} \mathrm{O}_{2}\left(\mathrm{O}_{2} \mathrm{CPh}\right)_{7}(\text { phen })_{2}\right]^{+}$ & -77.6 & -2.4 & Ref. 13 \\
\hline$\left[\mathrm{Fe}_{4} \mathrm{O}_{2}\left(\mathrm{O}_{2} \mathrm{CPh}\right)_{8}(\text { phen })_{2}\right]$ & -65.7 & -15.6 & Ref. 13 \\
\hline$\left[\mathrm{Fe}_{4} \mathrm{O}_{2}\left(\mathrm{CH}_{3} \mathrm{COO}\right)_{7}(\mathrm{BPA})_{2}\left(\mathrm{H}_{2} \mathrm{O}\right)\right]^{+}$ & -16.2 & -9.8 & This work \\
\hline
\end{tabular}

\section{Antibacterial activity and cytotoxicity}

Table 2 shows the antimicrobial effect of compound using the paper disk diffusion method. From the zone of bacterial grown inhibition, it is observed that all the complexes showed activity towards Gram negative bacteria analysed. In the other hand, against Gram positive bacteria we did not find any activity for the complex (1) and we find minimal activity for the complex (2) against Staphylococcus aureus. These results showed that both iron complexes synthesized in this work have not present significant activity over Gram positive strains.

The analysis of minimum inhibitory concentration included in table 3 showed that both complexes have MIC values slightly higher than ampicillin under conditions studied ( with MIC values around $60-70 \mu \mathrm{g} / \mathrm{mL}$ ).

We used a plate assay to distinguish a bacteriolytic from a bacteriostatic mode of action of antimicrobial complexes ${ }^{19}$. This method is based on the use of $\beta$-galactosidase as an appropriate marker of cellular lysis. If lysis occurs, then the enzyme is released outside the bacterium and detected on the plate. When the enzyme reaches the agar medium, it hydrolyzes the 5-bromo-4-chloro-3indolyl- $\beta$-D-galactoside (X-Gal), a chromogenic compound included in the agar. After overnight incubation, X-Gal forms a blue circle staining the edge of the inhibition zone produced by the antibiotic application. Only compounds causing cellular lysis produce a blue-colored edge at the inhibition zone. 
Table 2. Qualitative antibacterial activity of iron (III) complexes

\begin{tabular}{|l|c|c|c|c|}
\hline \multirow{2}{*}{ Bacteria } & \multicolumn{4}{|c|}{ Zone of inhibition (mm)* } \\
\cline { 2 - 5 } & $\begin{array}{c}\text { Fe/2MeIm } \\
\text { Gram positive }\end{array}$ & $\begin{array}{c}\text { Fe/BPA } \\
(2)\end{array}$ & Ampicillin & $\begin{array}{c}\text { Solvent** } \\
\text { (etanol) }\end{array}$ \\
\hline $\begin{array}{l}\text { Staphylococcus aureus } \mathrm{AB} 68 \\
\text { Bacillus cereus UDP356 }\end{array}$ & $\mathrm{R}$ & 9 & 29 & $\mathrm{R}$ \\
Gram negative & $\mathrm{R}$ & $\mathrm{R}$ & $\mathrm{R}$ & $\mathrm{R}$ \\
\hline Escherichia coli ATCC25922 & 18 & 17 & 24 & $\mathrm{R}$ \\
Klebsiella pneumoniae ATCC13833 & 15 & 15 & 23 & $\mathrm{R}$ \\
\hline
\end{tabular}

* Used disk with $400 \mu \mathrm{g}$ iron complexes and $400 \mu \mathrm{g}$ ampicillin. Number of assays $=3$, estimated error $\pm 1 \mathrm{~mm}$. $\mathrm{R}$ is resistant

** The solvent was added to paper disk over equals conditions to disk with iron complexes.

Table 3. Quantitative Antibacterial activity of iron (III) complexes.

\begin{tabular}{|l|c|c|c|}
\hline \multirow{2}{*}{\multicolumn{1}{|c|}{ Bacteria }} & \multicolumn{3}{|c|}{ MIC $(\mu \mathrm{g} / \mathbf{m L}) *$} \\
\cline { 2 - 4 } & $\begin{array}{c}\text { Fe/2MeIm } \\
(1)\end{array}$ & $\begin{array}{c}\text { Fe/BPA } \\
(2)\end{array}$ & Ampicillin \\
\hline Eschericia coli ATCC25922 & 75 & 70 & 62.5 \\
\hline Klebsiella pneumoniae ATCC 13833 & 55 & 70 & 62.5 \\
\hline Salmonella enteritidis UDP455 & 65 & 70 & 125 \\
\hline Pseudomonas aeruginosa SJD1 & 55 & 50 & $>1000$ \\
\hline
\end{tabular}

$*$ Number of assays $=3, \mathrm{R}$ is resistant.

The assay showed that both iron complexes present bacteriostatic activity because they do not produce a blue circle staining the edge of the inhibition zone (Figure 7). As controls, we used chloramphenicol and ampicillin as bacteriostatic and bacteriolytic agents, respectively.

The toxicity of iron complexes was tested on human kidney cells (Figure 8). The values of $\mathrm{IC}_{50}$ for (1) and (2) were 84.3 and $48.5 \mu \mathrm{M}$, respectively. It could be observed that complexes presented significant cytotoxicity effect at values around the MIC (70 $\mu \mathrm{M}$ and $60 \mu \mathrm{M}$ for (1) and (2) respectively). On the other hand, these complexes have not shown toxic effects at values one or two magnitude order less than the MIC.

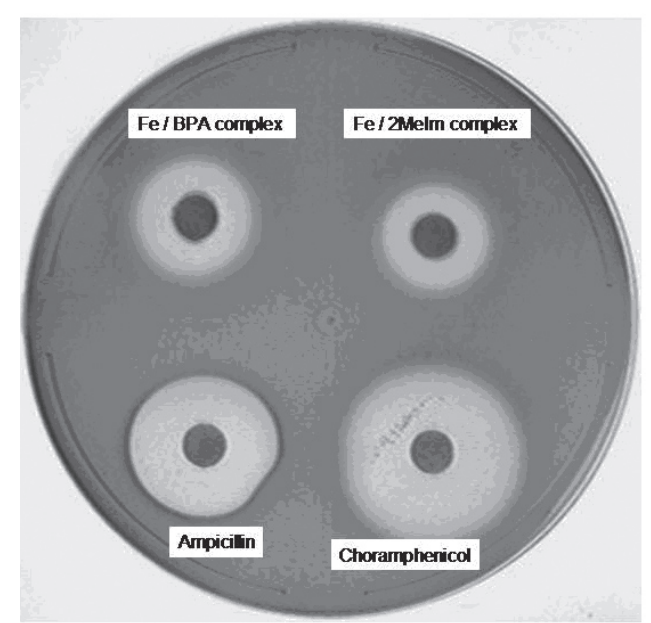

Figure 7. Plate assay showing bacteriostatic activity for the iron complexes. Ampicillin is a bacteriolytic control and chloramphenicol is a bacteriostatic control.
A

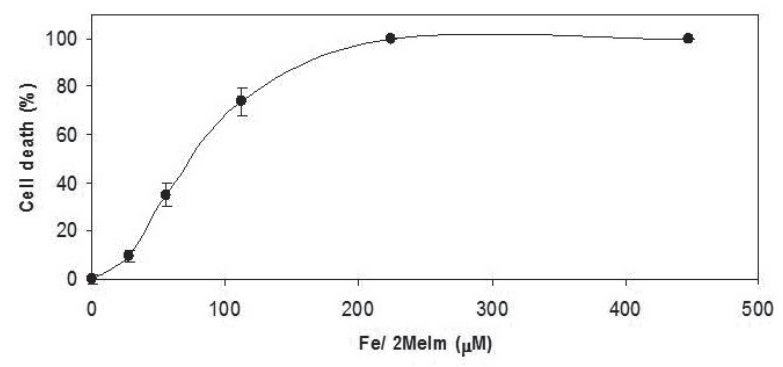

B

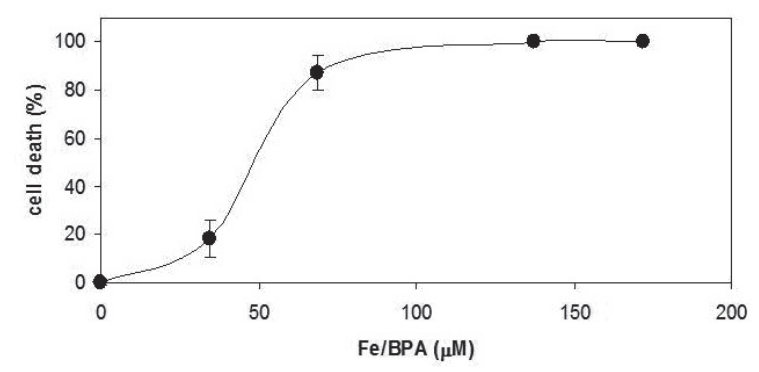

Figure 8. The Cytotoxicity effect over human cell of $\left[\mathrm{Fe}_{3} \mathrm{O}\left(\mathrm{CH}_{3} \mathrm{COO}\right)_{6}\right.$ $\left.\left(\mathrm{CH}_{3} \mathrm{COOH}\right)\left(\mathrm{H}_{2} \mathrm{O}\right)\right] \mathrm{Cl}$ (MeImid) $\left(\mathrm{H}_{2} \mathrm{O}\right)(\mathbf{1})$ (Plot A) and $\left[\mathrm{Fe}_{4}\left(\mathrm{CH}_{3} \mathrm{COO}\right)_{7} \mathrm{O}_{2}\right.$ $\left.(\mathrm{BPA})_{2}\left(\mathrm{H}_{2} \mathrm{O}\right)\right] \cdot \mathrm{Cl} \cdot 1.25\left(\mathrm{CH}_{3} \mathrm{CH}_{2} \mathrm{OH}\right)\left(\mathrm{H}_{2} \mathrm{O}\right)(2)$ (plot B) complexes.

\section{CONCLUSIONS}

A trimeric and tetrameric Fe(III) complexes have been synthesized, and characterized by magnetic measurements. The magnetic data of (1) and (2) show that the coupling between $\mathrm{Fe}(\mathrm{III})$-Fe(III) are antiferromagnetic in nature. These data are in qualitative agreement with complexes previously reported, although the intensity of the coupling is lower in this case.

Although these complexes have antibacterial activity through a bacteriostatic mechanism, they are cytotoxic to human cells. However, they could possibly be used as disinfectants since after being applied to a surface and later washed away, the toxicity would be very low since the remaining amounts are 10 to 100 -fold smaller than the MIC and the cell survival is between 95 to $99 \%$.

\section{ACKNOWLEDGMENT}

Proyecto Fondecyt 1020122. VRA Universidad Diego Portales.

\section{REFERENCES}

1. M. S Islam, M.A. Farooque, M.A.K.Bodruddoza, M.A. Mosaddik, M.S. Alam. J. Biol. Sci. 2, 797, ( 2002).

2. P.Cortés, A.M. Atria, M.T.Garland, R.Baggio, O. Peña, G. Corsini. J. Chil.Chem. Soc. 51,843, (2006).

3. P.Cortés, A.M. Atria, M. Contreras, M.T.Garland, O. Peña, G.Corsini. J. Chil. Chem. Soc. 51, 961, (2006).

4. R.R.Crichton . Inorganic Biochemistry of Iron Metabolism from Molecular Mechanisms to Clinical Consequences. John Wiley and Sons, Chichester and New York, 2001.

5. M.A. Holmes, R.E.Stenkamp, J. Biol. Mol. 220, 773,(1991).

6. A.C.Rosenzweig, C.A. Frederick, S.J.Lippard, P. Nordlund. Nature. 366, 537, (1993).

7. M.E.Holt, S.L. Holt, W.F. Tucker, N.D. Asplund, K.J. Watson. J. Am. Chem. Soc. 96, 2621, (1974).

8. S.M.Heald, E.A. Stearn, B. Bunker,E.Holt, S.L. Holt. J. Am. Soc. 101, 67, (1979).

9. P.C.Wilkins, R.G.Wilkins. Coord. Chem. Rev. 79, 195, (1987).

10. A.Ericson, B. Hedman, K.O. Hodgson, J. Green, H.Dalton, J.G. Bentsen, R.H. Beer, S.J. Lippard. J. Am. Chem. Soc. 110, 2330, (1988).

11. E.C.Theil. Annu. Rev. Biochem. 56, 289, (1987)

12. A.K.Boudalis,V. Tangoulis, C.P.Raptopoulou, A. Terzis, J.P. Tuchagues, S.P. Perlepes. Inorg. Chim. Acta. 357, 1345, (2004). 
13. A.K.Boudalis, N.Lalioti, G.A. Spyroulias, C.P. Raptopoulou, A. Terzis, A.Bousseksou, V. Tangoulis, J.P.Tuchagues, S.P. Perlepes. Inorg. Chem. 41, 6474, (2002).

14. J.K.McCusker, J.B.Vincent, E.A.Schmitt, M.L. Mino, K. Shin, D.K Coggin, P.M.Hagen, J. C.Huffman, G. Christou, D.N. Hendrickson. J. Am. Chem. Soc. 113, 3012, (1991).

15. P.Cortés, A.M. Atria, M.T. Garland, R. Baggio. Acta Cryst. C 62, m297,(2006).

16. A.Earnshaw. Introduction to Magnetochemistry. Academic Press; London, 1968.
17. K.L.Waniewska. Bull. Environ. Contam.Toxicol. 27, 289, (1981).

18. National Committee for Clinical Laboratory Standards. Methods for Dilution Antimicrobial Susceptibility Tests for Bacteria That Grow Aerobically-Fifth Edition: Approved Standard M7-A5; NCCLS, Wayne, PA, USA. 2000.

19. G.Mardones, A. Venegas. J. Microbiol. Meth., 40, 199, (2000).

20. R.Freshey. Culture of animal cells: a manual of basic technique; Alan R. Liss Inc., New York, p117, 1987.

21. S.M.Gorun, G.C. Papaefthymiou, R.B. Frankel, S.J. Lippard. J. Am. Chem. Soc.109, 4244. (1987). 